Rava, M., Tares, L., Lavi, I., Barreiro, E., Zock, J.P., Ferrer, A., Muniozquren, N., Nadif, R., Cazzoletti, L., Kauffmann, F., Antó, J.M., Guerra, S. Serum levels of Clara cell secretory protein, asthma, and lung function in the adult general population. Journal of Allergy and Clinical Immunology: 2013, 132(1), 230-232.e6

\begin{tabular}{|l|l|}
$\begin{array}{l}\text { Postprint } \\
\text { Version }\end{array}$ & 1.0 \\
\hline Journal website & $\underline{\text { http://www.jacionline.org/article/S0091-6749(13)00162-0/abstract }}$ \\
\hline Pubmed link & $\underline{\text { http://www.ncbi.nlm.nih.gov/pubmed/23473837 }}$ \\
\hline DOI & 10.1016/j.jaci.2013.01.023
\end{tabular}

This is a NIVEL certified Post Print, more info at http://www.nivel.eu

\title{
Serum levels of Clara cell secretory protein, asthma, and lung function in the adult general population
}

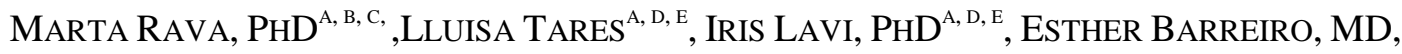
PHD $^{\mathrm{F}}$, JAN-PAUl Zock, PHD ${ }^{\mathrm{A}, \mathrm{D}, \mathrm{E}}$, ANNA FerRer, $\mathrm{MD}^{\mathrm{G}}$, Nerea MuniozGuren, $\mathrm{MD}^{\mathrm{H}}$, RACHEL NADIF, PHD ${ }^{\mathrm{B}, \mathrm{C}}$, LUCIA CAZZOLETTI, MS ${ }^{\mathrm{I}}$, FRANCINE KAUFFMANN, MD ${ }^{\mathrm{B}, \mathrm{C}}$, JOSEP M. ANTO, MD, PHD ${ }^{A, D, E, J}$, STEFANO GUERRA, MD, PHD ${ }^{A, D, E, K}$

${ }^{a}$ Centre for Research in Environmental Epidemiology (CREAL), Barcelona, Spain

b Inserm U1018, CESP Centre for Research in Epidemiology and Population Health, Respiratory and Environmental Epidemiology Team, Villejuif, France

${ }^{c}$ Université Paris Sud 11, Villejuif, France

d IMIM (Hospital del Mar Research Institute), Barcelona, Spain

e CIBER Epidemiología y Salud Pública (CIBERESP), Spain

${ }^{\dagger}$ Pulmonology Department-Muscle and Respiratory System Research Unit (URMAR), Hospital del Mar-IMIM, Parc de Recerca Biomèdica de Barcelona (PRBB), Barcelona, and Centro de Investigación en Red de Enfermedades Respiratorias (CIBERES), Instituto de Salud Carlos III (ISCIII), Bunyola, Majorca, Balearic Islands, Spain

${ }^{9}$ Hospital General de Almansa, Complejo Hospitalario Universitario de Albacete, Spain, and the Unit of Epidemiology and Health Information, Public Health of Bizkaia, Bizkaia, Spain

${ }^{\mathrm{h}}$ Department of Health, Basque Government, Bilbao, Basque Country, Spain

' Unit of Epidemiology and Medical Statistics, Department of Public Health and Community Medicine, University of Verona, Verona, Italy

j Universitat Pompeu Fabra, Barcelona, Spain

${ }^{k}$ Arizona Respiratory Center, University of Arizona, Tucson, Ariz

\section{TO THE EDITOR:}

Clara cell secretory protein (CC-16) has been proposed as a biological marker of lung epithelial injury and pulmonary permeability. It has anti-inflammatory properties and protective effects from oxidative stress on the respiratory tract. ${ }^{1}$ Acute exposures to pulmonary irritants such as smoke, chlorine, or ozone induce transient increases in serum CC-16 levels. In contrast, chronic exposures, such as smoking, occupational exposure to silica, and firefighting, are associated with decreased serum CC-16 levels. ${ }^{2 \text { and } 3}$ Clinical studies have shown decreased serum levels of CC-16 in asthmatic subjects ${ }^{4}$ and 5 and in patients with chronic obstructive pulmonary disease (COPD). ${ }^{6}$ A positive association between serum CC-16 levels and $\mathrm{FEV}_{1}$ was recently observed in a large clinical study on patients with COPD. ${ }^{7}$ However, there is a lack of epidemiological studies addressing the relation of serum CC-16 levels with asthma and lung function in the general population. 
Rava, M., Tares, L., Lavi, I., Barreiro, E., Zock, J.P., Ferrer, A., Muniozquren, N., Nadif, R., Cazzoletti, L., Kauffmann, F., Antó, J.M., Guerra, S. Serum levels of Clara cell secretory protein, asthma, and lung function in the adult general population. Journal of Allergy and Clinical Immunology: 2013, 132(1), 230-232.e6

In this study, we evaluated serum CC-16 level as a biomarker relevant in the study of asthma and lung function phenotypes in adults from the Spanish branch of the population-based multicenter European Community Respiratory Health Survey. We used a commercially available ELISA kit (BioVendor Laboratory, Inc, Modrice, Czech Republic) to measure CC-16 levels in serum samples from 859 participants (see Table E1 in this article's Online Repository at www.jacionline.org), of whom 642 (75\%) came from a random sample of the general population and 217 (25\%) from an enriched sample of subjects reporting asthma medication and/or respiratory symptoms. Ethical approval and written consent were obtained.

Subjects were defined as having physician-confirmed current asthma if they received an asthma diagnosis by a physician and they either experienced respiratory symptoms or used asthma medications in the previous 12 months. ${ }^{8}$ Prebronchodilator lung function (FEV ${ }_{1}$ and forced vital capacity [FVC]) was measured by using standard methods. Percent predicted values were calculated according to reference equations from the third National Health and Nutrition Examination Survey, as published by Hankinson et al. ${ }^{9}$ Airflow limitation was defined and classified according to the Global Initiative for Obstructive Lung Disease based on FEV 1 /FVC value of less than 0.70 . A second definition of airflow limitation based on the statistically defined lower limit of normal based on reference equations by Hankinson et $\mathrm{al}^{9}$ was used. A restrictive spirometric pattern was defined as FVC\% predicted value of less than $80 \%$ in the absence of airflow limitation.

Associations between serum CC-16 levels (as an independent variable) and asthma, spirometric patterns, the modified prebronchodilator Global Initiative for Obstructive Lung Disease COPD stages, and lung function parameters (as outcomes) were estimated with logistic, multinomial, or linear regression models, where appropriate. Estimates were adjusted for center and type of sample, sex, age, body mass index, smoking status and pack-years, and height (when needed). Mean serum CC-16 levels were $5.8 \pm 2.9 \mu \mathrm{g} / \mathrm{L}$, ranging from 0.37 to $19.7 \mu \mathrm{g} / \mathrm{L}$. Serum CC-16 levels were higher in males than in females, varied with age, and decreased with increasing body mass index, current smoking, and pack-years smoked (see Table E2 in this article's Online Repository at www.jacionline.org). Serum CC16 levels did not vary with current asthma in the total population (Table I). However, lower serum CC-16 levels were associated with current asthma among never smokers (see Table E3 in this article's Online Repository at www.jacionline.org). Decreased CC-16 levels were observed in subjects with airflow limitation and, in particular, in subjects with moderate/severe GOLD COPD stages as compared to subjects with no airflow limitation (Table I). These results were confirmed when serum CC-16 levels were categorized according to quartiles (see Fig E1 in this article's Online Repository at www.jacionline.org). The spirometric restrictive pattern was not associated with serum CC-16 levels, but it should be noted that the sample size for this spirometric pattern was small in our study.

\section{[TABLE I]}

A positive association was observed between serum CC-16 levels and $\mathrm{FEV}_{1} \%$ predicted and $\mathrm{FEV}_{1} / \mathrm{FVC}$ (Table I). When analyses were restricted to the 634 subjects from the random sample, we found very similar estimates of serum CC-16 level effects on $\mathrm{FEV}_{1} \%$ predicted, $\mathrm{FVC} \%$ predicted, and $\mathrm{FEV}_{1} / \mathrm{FVC}$ (adjusted beta coefficients [P], 1.71 [.002], 0.61 [.23], and 0.89 [<.001], respectively). When serum 
Rava, M., Tares, L., Lavi, I., Barreiro, E., Zock, J.P., Ferrer, A., Muniozquren, N., Nadif, R., Cazzoletti, L., Kauffmann, F., Antó, J.M., Guerra, S. Serum levels of Clara cell secretory protein, asthma, and lung function in the adult general population. Journal of Allergy and Clinical Immunology: 2013, 132(1), 230-232.e6

CC-16 levels were categorized into quartiles, the lowest quartile was consistently associated with the lowest levels of $\mathrm{FEV}_{1}, \mathrm{FVC}$, and $\mathrm{FEV}_{1} / \mathrm{FVC}$ ( Fig 1).

\section{[FIG 1]}

Analyses were repeated after stratification by asthma and smoking (see Fig E2 and Fig E3 in this article’s Online Repository at www.jacionline.org). The interaction term between current asthma and serum CC-16 levels was borderline significant for $\mathrm{FEV}_{1} \%$ predicted $(P=.08)$ and statistically significant for $\mathrm{FEV}_{1} / \mathrm{FVC}(P=.007)$, suggesting that the effects of serum CC-16 levels on lung function may be stronger among asthmatic subjects. However, these interactions should be interpreted with caution because of the relatively small number of asthmatic subjects. The association between serum CC-16 levels and lung function parameters did not vary with smoking habits.

In this study, we observed decreased serum CC-16 levels to be associated with airflow limitation and lower lung function in the general population. We did not find serum CC-16 levels to be associated with asthma. To date, most evidence of an association between serum CC-16 levels and asthma comes from clinical studies. A possible explanation for this apparent discrepancy is that participants from clinical studies are likely to have more severe asthma than participants from populationbased studies. This scenario is supported by the positive correlation that we found between serum CC-16 levels and lung function among asthmatic subjects. In addition, in our study, the association between serum CC-16 levels and asthma may have been affected by the complex interrelationships between smoking, serum CC-16 levels, and asthma, as suggested by the finding that lower serum CC-16 levels were associated with asthma among never smokers but not among ever smokers. Larger studies with well-characterized phenotypic information on asthma are required to determine conclusively its relation with serum CC-16 levels. A positive association between serum CC-16 levels and lung function has been reported in clinical studies ${ }^{7}$ and in occupationally exposed subjects. ${ }^{3 \text { and } 6}$ We extended these findings to adults from the general population by showing a positive association between serum CC-16 levels and $\mathrm{FEV}_{1} \%$ predicted and $\mathrm{FEV}_{1} / \mathrm{FVC}$ ratio and a borderline positive association with FVC\% predicted. All the associations were confirmed after adjustment for relevant covariates, including smoking. Thus, serum CC-16 levels may provide additional information that is complementary to and partially independent of demographics and smoking in relation to lung function parameters at the population level. Consistently, we observed a low level of serum CC-16 in subjects with airflow limitation, particularly in those in the moderate to severe COPD stages, in line with the association between serum CC-16 levels and COPD and COPD severity shown by Lomas et al. ${ }^{6}$ Because associations of serum CC-16 levels with lung function held true after adjusting for smoke and pack-years and after stratification by smoking, we concluded that these associations were at least partly independent of smoking.

A strength of this analysis is that it was conducted on a large and well-characterized sample of the general population. Detailed phenotypic data were available from questionnaires and spirometric tests. Asthma cases were population-based, and associations with lung function parameters were confirmed both in the total and in the random sample of the study. Thus, our findings indicate that the serum CC-16 level is a potential biomarker of lung function deficits in the general population. 
Rava, M., Tares, L., Lavi, I., Barreiro, E., Zock, J.P., Ferrer, A., Muniozquren, N., Nadif, R., Cazzoletti, L., Kauffmann, F., Antó, J.M., Guerra, S. Serum levels of Clara cell secretory protein, asthma, and lung function in the adult general population. Journal of Allergy and Clinical< 7 Immunology: 2013, 132(1), 230-232.e6

However, because of the cross-sectional approach of the study, it was not possible to evaluate the temporal relationship of the biomarker to lung function or disease status and longitudinal studies are warranted to resolve the temporality of this association and to evaluate any potential role of this biomarker in the prevention or clinical settings.

In summary, we found reduced serum CC-16 levels to be associated with airflow limitation and lower lung function in the general population after adjusting for the effects of cigarette smoking and other covariates. These data warrant evaluation of serum CC-16 level as a potential biomarker of lung function deficits and obstructive lung disease in the longitudinal setting.

\section{APPENDIX}
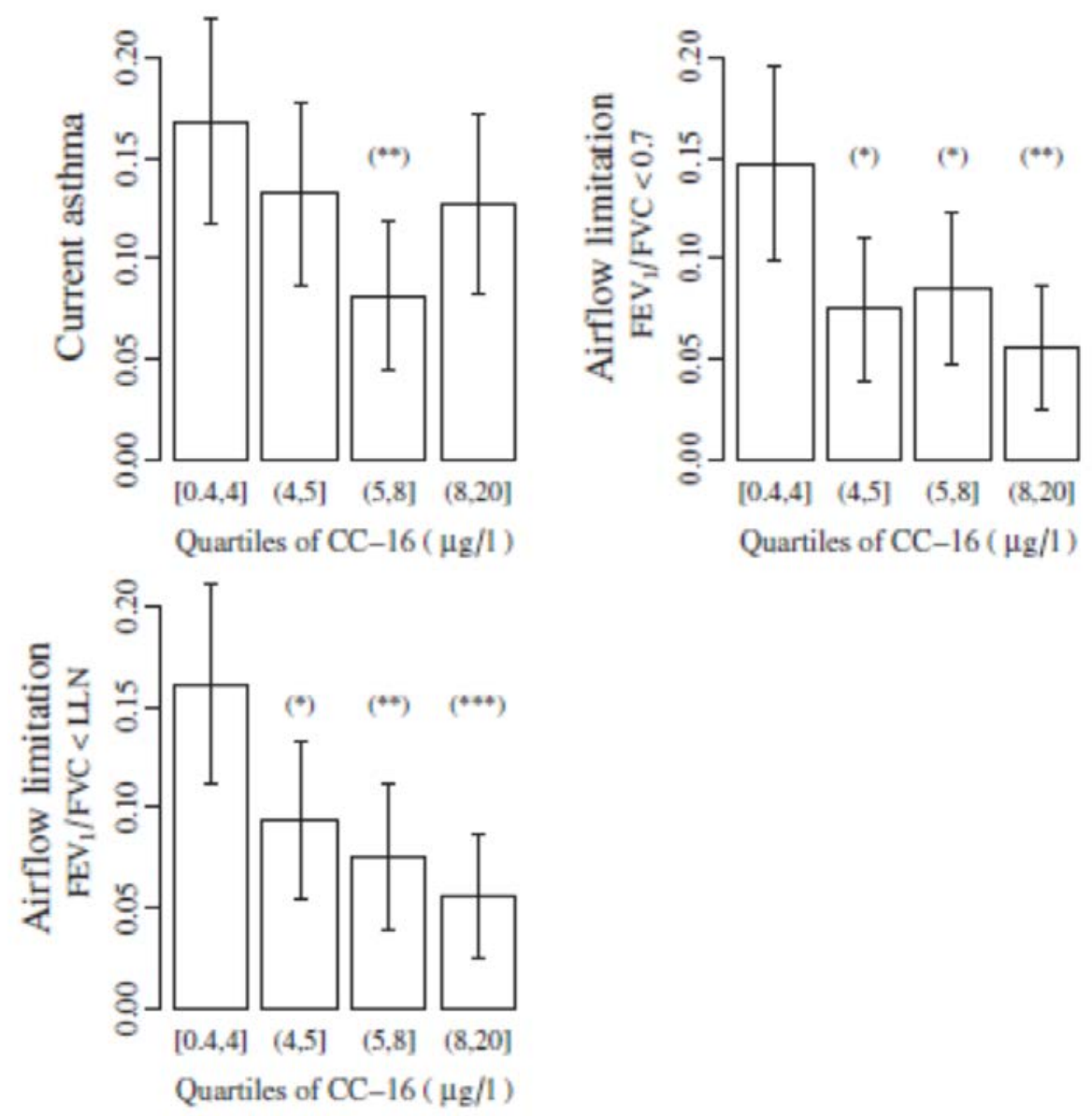

FG E1. Prevalence of asthma and airflow limitation by quartiles of serum CC-16 levels. Asterisks repre sent $P$ values obtained by comparing the unadjusted odds ratio of having the outcome for each quartile of the serum CC-16 level, using the first quartile as reference. LLN, Lower limit of normal. ${ }^{*} P<.10, * * P<.05$, and $* * P<.001$. 
Rava, M., Tares, L., Lavi, I., Barreiro, E., Zock, J.P., Ferrer, A., Muniozquren, N., Nadif, R., Cazzoletti, L., Kauffmann, F., Antó, J.M., Guerra, S. Serum levels of Clara cell secretory protein, asthma, and lung function in the adult general population. Journal of Allergy and Clinical Immunology: 2013, 132(1), 230-232.e6

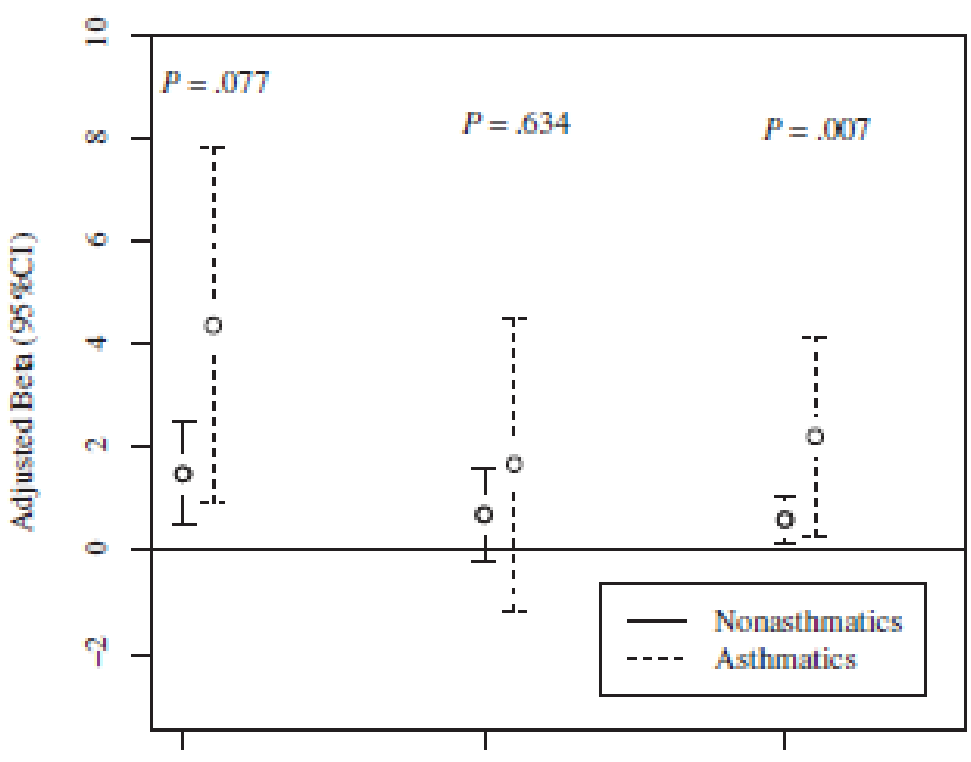

FEV1\% predicted FVC\% predicted FEV1/FVC

FIG E2. Adjusted regression coefficients (beta) and $95 \% \mathrm{Cl}$ for the association between serum CC-16 levels and lung function parameters, estimated through a multivariate linear regression model, stratified by asthma status. The $P$ values refer to the interaction between asthma status and serum CC-16 levels.

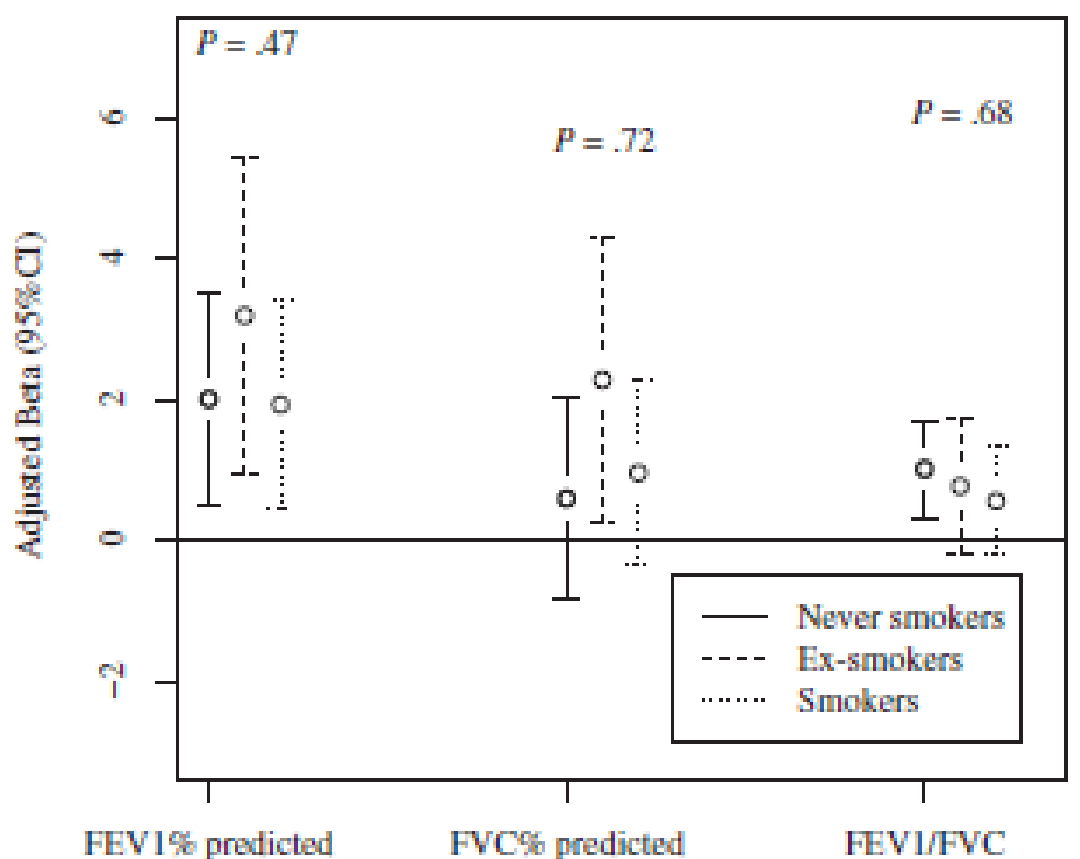

FIG E3. Adjusted regression coefficients (beta) and $95 \% \mathrm{Cl}$ for the association between serum CC-16 levels and lung function parameters, estimated through a multivariate linear regression model, stratified by smoking status. The $P$ values refer to the interaction between smoking stat us and serum CC-16 levels. 
Rava, M., Tares, L., Lavi, I., Barreiro, E., Zock, J.P., Ferrer, A., Muniozquren, N., Nadif, R., Cazzoletti, L., Kauffmann, F., Antó, J.M., Guerra, S. Serum levels of Clara cell secretory protein, asthma, and lung function in the adult general population. Journal of Allergy and Clinical Immunology: 2013, 132(1), 230-232.e6

Table E1. Sociodemographic and clinical characteristics of the study subjects

\begin{tabular}{|c|c|}
\hline & All subjects $(\mathrm{N}=\mathbf{8 5 9})$ \\
\hline \multicolumn{2}{|l|}{ Subjects characteristics, n (\%) } \\
\hline \multicolumn{2}{|l|}{ Center } \\
\hline Barcelona & $199(23.2)$ \\
\hline Galdakao & $343(39.9)$ \\
\hline Albacete & 317 (36.9) \\
\hline Enriched sample & $217(25.4)$ \\
\hline Sex (men) & $422(49.4)$ \\
\hline \multicolumn{2}{|l|}{ Age $(y)$} \\
\hline $28.0-32.4$ & $132(15.5)$ \\
\hline $32.5-39.9$ & $263(30.8)$ \\
\hline $40.0-47.4$ & $257(30.1)$ \\
\hline$\geq 47.5$ & $202(23.7)$ \\
\hline \multicolumn{2}{|l|}{ BMI $\left(\mathrm{kg} / \mathrm{m}^{2}\right)$} \\
\hline$<20$ & $25(2.9)$ \\
\hline $20-24.9$ & $324(38.1)$ \\
\hline $25-29.9$ & $343(40.3)$ \\
\hline$\geq 30$ & $159(18.7)$ \\
\hline \multicolumn{2}{|l|}{ Smoking status and intensity } \\
\hline Never smokers & $288(34.3)$ \\
\hline Ex-smokers $\leq 20$ pack-years & $112(13.5)$ \\
\hline Ex-smokers $>20$ pack-years & $66(7.9)$ \\
\hline Current smokers $\leq 20$ pack-years & $194(23.4)$ \\
\hline Current smokers $>20$ pack-years & $171(20.6)$ \\
\hline \multicolumn{2}{|l|}{ Respiratory diseases/phenotypes, n (\%) } \\
\hline Current asthma & $108(12.7)$ \\
\hline \multicolumn{2}{|l|}{ Obstructive/restrictive spirometric patterns } \\
\hline \multicolumn{2}{|l|}{ Definition based on $\mathrm{FEV}_{1} / \mathrm{FVC}<70 \% *$} \\
\hline Normals & $746(87.7)$ \\
\hline Spirometric restrictive pattern & $28(3.3)$ \\
\hline Airflow limitation & $77(9.0)$ \\
\hline \multicolumn{2}{|l|}{ Definitions based on $\mathrm{FEV}_{1} / \mathrm{FVC}<\mathrm{LLN} \dagger$} \\
\hline Normals & $741(87.1)$ \\
\hline Spirometric restrictive pattern & $28(3.3)$ \\
\hline
\end{tabular}


Rava, M., Tares, L., Lavi, I., Barreiro, E., Zock, J.P., Ferrer, A., Muniozquren, N., Nadif, R., Cazzoletti, L., Kauffmann, F., Antó, J.M., Guerra, S. Serum levels of Clara cell secretory protein, asthma, and lung function in the adult general population. Journal of Allergy and Clinical Immunology: 2013, 132(1), 230-232.e6

\begin{tabular}{|l|l|}
\hline & All subjects (N = 859) \\
\hline \hline Airflow limitation & $82(9.6)$ \\
\hline Modified GOLD COPD stages $\ddagger$ & \\
\hline No & $774(91.0)$ \\
\hline Mild & $35(4.1)$ \\
\hline Moderate/severe & $42(4.9)$ \\
\hline \hline Lung function, mean \pm SD & \\
\hline FEV $\%$ predicted & $100.2 \% \pm 14.8 \%$ \\
\hline FVC $\%$ predicted & $101.6 \% \pm 12.2 \%$ \\
\hline \hline FEV 1 /FVC & $79.5 \% \pm 7.2 \%$ \\
\hline CC-16 $(\mu \mathrm{g} / \mathrm{L})$ & \\
\hline \hline Mean \pm SD & $5.79 \pm 2.9$ \\
\hline \hline Median $(\mathrm{Q} 1-\mathrm{Q} 3)$ & $5.34(3.64,7.52)$ \\
\hline
\end{tabular}

$B M I$, Body mass index; GOLD, Global Initiative for Obstructive Lung Disease; $L L N$, lower limit of normal; $Q$, quartile.

* Airflow limitation defined as $\mathrm{FEV}_{1} / \mathrm{FVC}<0.70$, and restrictive spirometric pattern defined as $\mathrm{FVC} \%$ predicted $<80 \%$ and $\mathrm{FEV}_{1} / \mathrm{FVC} \geq 0.70$.

$\dagger$ Airflow limitation defined as $\mathrm{FEV}_{1} / \mathrm{FVC}<\mathrm{LLN}$, and restrictive spirometric pattern defined as FVC\% predicted $<80 \%$ and $\mathrm{FEV}_{1} / \mathrm{FVC} \geq \mathrm{LLN}$.

$\ddagger$ Stages are based on lung function tests with no bronchodilator. 
Rava, M., Tares, L., Lavi, I., Barreiro, E., Zock, J.P., Ferrer, A., Muniozquren, N., Nadif, R., Cazzoletti, L., Kauffmann, F., Antó, J.M., Guerra, S. Serum levels of Clara cell secretory protein, asthma, and lung function in the adult general population. Journal of Allergy and Clinical Immunology: 2013, 132(1), 230-232.e6

Table E2. Association between sociodemographic characteristics and serum CC-16 levels

\begin{tabular}{|c|c|c|c|}
\hline & $\mathbf{n}$ & \begin{tabular}{|c|} 
Serum CC-16 level, mean \\
\pm SD
\end{tabular} & Beta* \\
\hline \multicolumn{4}{|l|}{ Sex } \\
\hline Female & 433 & $5.52 \pm 2.89 \dagger$ & \\
\hline Male & 422 & $6.07 \pm 2.92$ & $1.05 \ddagger$ \\
\hline \multicolumn{4}{|l|}{ Age (y) } \\
\hline $28-32.4$ & 132 & $6.61 \pm 3.38 \S$ & \\
\hline 32.5-39.9 & 263 & $5.68 \pm 2.67$ & $-0.87 \dagger$ \\
\hline $40.0-47.4$ & 257 & $5.51 \pm 2.86$ & \begin{tabular}{|l|l|}
$-0.76 \S$ \\
\end{tabular} \\
\hline$\geq 47.5$ & 202 & $5.74 \pm 2.90$ & $-0.65 \S$ \\
\hline \multicolumn{4}{|l|}{ BMI $\left(\mathrm{kg} / \mathrm{m}^{2}\right)$} \\
\hline$<20$ & 25 & $6.39 \pm 3.57 \dagger$ & 0.72 \\
\hline 20-24.9 (reference) & 324 & $6.12 \pm 3.09$ & \\
\hline $25-29.9$ & 343 & $5.67 \pm 2.69$ & $-0.57 \S$ \\
\hline$\geq 30$ & 159 & $5.31 \pm 2.86$ & $-1.01 \ddagger$ \\
\hline \multicolumn{4}{|l|}{$\begin{array}{l}\begin{array}{l}\text { Smoking status and intensity (pack- } \\
\text { years) }\end{array} \\
\end{array}$} \\
\hline Never smokers & 288 & $6.45 \pm 2.59 \ddagger$ & \\
\hline Ex-smokers $\leq 20$ pack-years & 112 & $6.26 \pm 2.56$ & -0.08 \\
\hline Ex-smokers $>20$ pack-years & 66 & $5.75 \pm 2.55$ & $-0.84 \dagger$ \\
\hline Current smokers $\leq 20$ pack-years & 194 & $5.73 \pm 3.26$ & $-0.94 \ddagger$ \\
\hline Current smokers $>20$ pack-years & 171 & $4.31 \pm 2.88$ & $-2.42 \ddagger$ \\
\hline
\end{tabular}

BMI, Body mass index.

* Coefficients and $P$ values from 1 multivariate regression model with center and type of sample, sex, age, BMI, and smoking status (5-level variable) as covariates and the serum CC-16 level as the outcome variable.

$\dagger$ Overall $P$ value for the association between each subject characteristic and the serum CC-16 level: $P<.05$.

$\ddagger$ Overall $P$ value for the association between each subject characteristic and the serum CC-16 level: $P<.001$.

$\S$ Overall $P$ value for the association between each subject characteristic and the serum CC-16 level: $P<.10$. 
Rava, M., Tares, L., Lavi, I., Barreiro, E., Zock, J.P., Ferrer, A., Muniozquren, N., Nadif, R., Cazzoletti, L., Kauffmann, F., Antó, J.M., Guerra, S. Serum levels of Clara cell secretory protein, asthma, and lung function in the adult general population. Journal of Allergy and Clinical Immunology: 2013, 132(1), 230-232.e6

Table E3. Adjusted odds ratios (ORs, 95\% CI) for the association between a $1-S D$ increase in the serum CC-16 level $(\mu \mathrm{g} / \mathrm{L})$ and asthma stratified by smoking status*

\begin{tabular}{||l||c||c||c||}
\hline $\begin{array}{l}\text { Current } \\
\text { asthma }\end{array}$ & $\begin{array}{c}\text { n (asthmatic } \\
\text { subjects/nonasthmatic } \\
\text { subjects) }\end{array}$ & $\begin{array}{c}\text { Serum CC-16 average } \\
\text { levels (in asthmatic } \\
\text { subjects/in } \\
\text { nonasthmatic subjects) }\end{array}$ & $\begin{array}{c}\text { Adjusted } \\
\text { OR } \dagger \text { (95\% } \\
\text { CI) }\end{array}$ \\
\hline $\begin{array}{l}\text { Never } \\
\text { smokers }\end{array}$ & $35 / 250$ & $5.52 / 6.58$ & $\begin{array}{l}0.5(0.3- \\
0.9) \ddagger\end{array}$ \\
\hline $\begin{array}{l}\text { Ex- } \\
\text { smokers }\end{array}$ & $23 / 155$ & $5.86 / 6.13$ & $\begin{array}{l}0.8(0.4- \\
1.5)\end{array}$ \\
\hline $\begin{array}{l}\text { Current } \\
\text { smokers }\end{array}$ & $47 / 323$ & $5.40 / 5.04$ & $\begin{array}{l}1.2(0.9- \\
1.7)\end{array}$ \\
\hline
\end{tabular}

$B M I$, Body mass index.

$* P$ value for interaction between serum CC-16 levels and smoking status $=.006$. †ORs (95\% CI) were estimated with logistic regression models adjusted for center and type of sample (6-level variable), sex, age (categorical), and BMI (categorical). $\ddagger P$ value for the association between asthma and the serum CC-16 level: $P<.05$.

\section{REFERENCES}

$1 \mathrm{~F}$. Broeckaert, A. Bernard Clara cell secretory protein (CC16): characteristics and perspectives as lung peripheral biomarker Clin Exp Allergy, 30 (2000), pp. 469-475

2 J.S. Lakind, S.T. Holgate, D.R. Ownby, A.H. Mansur, P.J. Helms, D. Pyatt et al. A critical review of the use of Clara cell secretory protein (CC16) as a biomarker of acute or chronic pulmonary effects Biomarkers, 12 (2007), pp. 445-467

3 F. Greven, E. Krop, N. Burger, H. Kerstjens, D. Heederik Serum pneumoproteins in firefighters Biomarkers, 16 (2011), pp. 364-371

4 N. Shijubo, Y. Itoh, T. Yamaguchi, F. Sugaya, M. Hirasawa, T. Yamada et al. Serum levels of Clara cell 10-kDa protein are decreased in patients with asthma Lung, 177 (1999), pp. 45-52

5 Q. Ye, M. Fujita, H. Ouchi, I. Inoshima, T. Maeyama, K. Kuwano et al. Serum CC-10 in inflammatory lung diseasesRespiration, 71 (2004), pp. 505-510

6D.A. Lomas, E.K. Silverman, L.D. Edwards, B.E. Miller, H.O. Coxson, R. TalSingerEvaluation of serum CC-16 as a biomarker for COPD in the ECLIPSE cohortThorax, 63 (2008), pp. 1058-1063

7J. Vestbo, L.D. Edwards, P.D. Scanlon, J.C. Yates, A. Agusti, P. Bakke et al.Changes in forced expiratory volume in 1 second over time in COPDN Engl J Med, 365 (2011), pp. 1184-1192

8L. Cazzoletti, A. Marcon, A. Corsico, C. Janson, D. Jarvis, I. Pin et al.Asthma severity according to Global Initiative for Asthma and its determinants: an international studyInt Arch Allergy Immunol, 151 (2010), pp. 70-79J.L. Hankinson, J.R. Odencrantz, K.B. FedanSpirometric reference values from a sample of the general U.S. populationAm J Respir Crit Care Med, 159 (1999), pp. 179-187

\section{TABLES AND FIGURES}


Rava, M., Tares, L., Lavi, I., Barreiro, E., Zock, J.P., Ferrer, A., Muniozquren, N., Nadif, R., Cazzoletti, L., Kauffmann, F., Antó, J.M., Guerra, S. Serum levels of Clara cell secretory protein, asthma, and lung function in the adult general population. Journal of Allergy and Clinical Immunology: 2013, 132(1), 230-232.e6

Table I. Unadjusted and adjusted estimates (95\% CI and $P$ ) for the association between a 1-SD increase in serum CC-16 level $(\mu \mathrm{g} / \mathrm{L})$ and asthma, spirometric patterns, and lung function

\begin{tabular}{|c|c|c|c|c|c|}
\hline \multirow{2}{*}{ Outcome } & \multirow{2}{*}{$\mathbf{n}$} & \multicolumn{2}{|c|}{ Unadjusted } & \multicolumn{2}{|l|}{ Adjusted } \\
\hline & & \begin{tabular}{|c|} 
Est $(95 \%$ \\
CI)
\end{tabular} & $\begin{array}{c}P \\
\text { value }\end{array}$ & Est (95\% CI) & $\begin{array}{c}P \\
\text { value }\end{array}$ \\
\hline \multicolumn{6}{|l|}{ Asthma } \\
\hline Current asthma* & $108 / 848$ & \begin{tabular}{|l}
$\mathrm{OR}=0.90$ \\
$(0.73-$ \\
$1.10)$
\end{tabular} & .32 & $\begin{array}{l}\text { Adjusted OR = } \\
0.93(0.72-1.17)\end{array}$ & .53 \\
\hline \multicolumn{6}{|l|}{ Spirometric patterns } \\
\hline \multicolumn{6}{|c|}{$\begin{array}{l}\text { Definition based on } \\
\text { FEV }_{1} / \text { FVC }<70 \% \text { and } \\
\end{array}$} \\
\hline Normal & 746 & $\mathrm{RRR}=1$ & & \begin{tabular}{|l} 
Adjusted RRR $=$ \\
1
\end{tabular} & \\
\hline Restrictive & 28 & $\begin{array}{l}0.94(0.64- \\
1.38)\end{array}$ & .74 & $1.10(0.71-1.69)$ & .68 \\
\hline Airflow limitation & 77 & \begin{tabular}{|l|}
$0.66(0.51-$ \\
$0.87)$
\end{tabular} & .003 & $0.71(0.52-0.96)$ & .03 \\
\hline \multicolumn{6}{|c|}{\begin{tabular}{|l} 
Definition based on \\
FEV $_{1} /$ FVC $<$ LLN and \\
\end{tabular}} \\
\hline Normal & 741 & $\mathrm{RRR}=1$ & & $\begin{array}{l}\text { Adjusted RRR = } \\
1\end{array}$ & \\
\hline Restrictive & 28 & $\begin{array}{l}0.93(0.64- \\
1.37) \\
\end{array}$ & .73 & $1.10(0.71-1.69)$ & .67 \\
\hline Airflow limitation & 82 & $\begin{array}{l}0.65(0.50- \\
0.85)\end{array}$ & .002 & $0.72(0.54-0.97)$ & .029 \\
\hline \multicolumn{6}{|c|}{$\begin{array}{l}\text { Modified GOLD COPD } \\
\text { stages and }\end{array}$} \\
\hline No (reference) & 774 & $\mathrm{RRR}=1$ & & $\begin{array}{l}\text { Adjusted RRR = } \\
1\end{array}$ & \\
\hline Mild & 35 & $\begin{array}{l}0.95(0.67- \\
1.34)\end{array}$ & .76 & $0.88(0.60,1.30)$ & .52 \\
\hline Moderate/severe & 42 & \begin{tabular}{|l|}
$0.45(0.30-$ \\
$0.68)$
\end{tabular} & $<.001$ & $0.52(0.32,0.85)$ & .01 \\
\hline \multicolumn{6}{|l|}{ Lung function } \\
\hline $\mathrm{FEV}_{1} \%$ predicted & 851 & \begin{tabular}{|l|} 
Beta $=$ \\
$2.83(1.85-$ \\
$3.80)$ \\
\end{tabular} & $<.001$ & $\begin{array}{l}\text { Adjusted beta = } \\
1.92(0.96-2.88)\end{array}$ & $<.001$ \\
\hline FVC\% predicted & 851 & Beta $=$ & $<.001$ & Adjusted beta $=$ & .06 \\
\hline
\end{tabular}


Rava, M., Tares, L., Lavi, I., Barreiro, E., Zock, J.P., Ferrer, A., Muniozquren, N., Nadif, R., Cazzoletti, L., Kauffmann, F., Antó, J.M., Guerra, S. Serum levels of Clara cell secretory protein, asthma, and lung function in the adult general population. Journal of Allergy and Clinical Immunology: 2013, 132(1), 230-232.e6

\begin{tabular}{|c|c|c|c|c|c|}
\hline \multirow{2}{*}{ Outcome } & \multirow{2}{*}{$\mathbf{n}$} & \multicolumn{2}{|c|}{ Unadjusted } & \multicolumn{2}{|l|}{ Adjusted } \\
\hline & & $\begin{array}{c}\text { Est (95\% } \\
\text { CI) }\end{array}$ & $\begin{array}{c}P \\
\text { value }\end{array}$ & Est (95\% CI) & $\begin{array}{c}P \\
\text { value }\end{array}$ \\
\hline & & $\begin{array}{l}1.50(0.65- \\
2.35)\end{array}$ & & $\begin{array}{l}0.84(-0.02 \text { to } \\
1.71)\end{array}$ & \\
\hline $\mathrm{FEV}_{1} / \mathrm{FVC}$ & 851 & $\begin{array}{l}\text { Beta }= \\
1.16(0.68- \\
1.63)\end{array}$ & $<.001$ & $\begin{array}{l}\text { Adjusted beta }= \\
0.84(0.38-1.30)\end{array}$ & $<.001$ \\
\hline
\end{tabular}

$B M I$, Body mass index; GOLD, Global Initiative for Obstructive Lung Disease; $L L N$, lower limit of normal; $O R$, odds ratio; $R R R$, relative risk ratio.

* ORs (95\% CI) were estimated with logistic regression models unadjusted and adjusted for center and type of sample (6-level variable), sex, age (categorical), BMI (underweight, $<20 \mathrm{~kg} / \mathrm{m}^{2}$; normal weight, $20-25 \mathrm{~kg} / \mathrm{m}^{2}$; overweight, 25-30 kg/m²; or obese, $>30 \mathrm{~kg} / \mathrm{m}^{2}$ ), smoking status and pack-years (never smokers, ex-smokers who smoked $\leq 20$ pack-years, ex-smokers who smoked $>20$ pack-years, current smokers with $\leq 20$ pack-years, and current smokers with $>20$ pack-years), and height (when needed).

† RRRs (95\% CI) were estimated with multinomial regression models unadjusted and adjusted for center and sample, sex, age (categorical), BMI (categorical), and smoking status (5-level variable).

$\ddagger$ Airflow limitation defined as $\mathrm{FEV}_{1} / \mathrm{FVC}<0.70$, and restrictive spirometric pattern defined as $\mathrm{FVC} \%$ predicted $<80 \%$ and $\mathrm{FEV}_{1} / \mathrm{FVC} \geq 0.70$.

$\S$ Airflow limitation defined as $\mathrm{FEV}_{1} / \mathrm{FVC}<\mathrm{LLN}$, and restrictive spirometric pattern defined as $\mathrm{FVC} \%$ predicted $<80 \%$ and $\mathrm{FEV}_{1} / \mathrm{FVC} \geq \mathrm{LLN}$.

$\vdots$ Stages are based on lung function tests with no bronchodilator.

I Estimates obtained with a linear regression model, adjusted for center and sample, age (categorical), BMI (categorical), and smoking status (5-level variable); estimates for $\mathrm{FEV}_{1} / \mathrm{FVC}$ were also adjusted for sex and height. 